\title{
Swedish Folk High Schools and Inclusive Education
}

Dörte Bernhard and Per Andersson

The self-archived version of this journal article is available at Linköping University Electronic Press:

http://urn.kb.se/resolve?urn=urn:nbn:se:liu:diva-139773

N.B.: When citing this work, cite the original publication.

Bernhard, D., Andersson, P., (2017), Swedish Folk High Schools and Inclusive Education, Nordic Studies in Education, 37(2), 87-102. https://dx.doi.org/10.18261/issn.1891-5949-2017-02-03

Original publication available at:

https://dx.doi.org/10.18261/issn.1891-5949-2017-02-03

Copyright: Universitetsforlaget (Scandinavian University Press)

http://www.universitetsforlaget.no/ 


\section{abstract Forum}

Dörte Bernhard and Per Andersson: Swedish Folk High Schools and Inclusive Education. Nordic Studies in Education, Vol. 37, 2-2017, pp. 87-102. ISSN |89|-59|4.

(C) Universitetsforlaget

This article focuses on Swedish folk high schools' participants with disabilities, and their learning environment within adult education. Facilitating factors are presented and discussed, as well as developmental factors regarding the adjustment of the learning environment. The basis for this empirical study is data from Statistics Sweden and a selfdesigned online questionnaire with respondents representing the folk high schools $(\mathrm{N}=2 \mid 2)$. Theoretical reference is given to concepts such as adult education and inclusive education. The results show there are an increased number of participants with disabilities in Swedish folk high schools. Furthermore, the study emphasizes the meaning of pedagogics with a personalized, individualized approach, and highlights a need for further education of adult educators about disability.

The conclusion is that a stronger inclusive-education perspective with focus on learners' diversity reflects only one side of practice, as this practice is also challenged by welfare system-steered processes that may conflict with an ideal of adult education as empowerment.

Keywords: folk high school . adult education - disability . inclusion - inclusive education . special needs $\cdot$ learning environment

Manuscript received: $\quad$ 15.09.16 (peer reviewed 15.03.17)

Dörte Bernhard Linköping University, Department of behavioural sciences and learning e-mail: dorte.bernhard@liu.se

Per Andersson e-mail: per.andersson@liu.se

\section{Swedish Folk High}

Schools and Inclusive

Education

Dörte Bernhard AND Per ANDERsson

\section{Introduction}

Adult education provides learning opportunities for all adults, throughout their whole lives, and becomes especially relevant for disadvantaged groups in order to create new possibilities for personal development, active inclusion, and enhanced social participation in society (European Commission, 2011). With this meaning, adult education serves as inclusive education. In the case of Sweden, education for adults is delivered mainly by municipal adult education and folk high schools, both of which provide for students who have failed in compulsory and/or upper secondary school. Whereas the history of municipal adult education founded in 1968 is quite short, the folk high school has roots going back to the mid-nineteenth century. The folk high school started by providing folkbildning, and by so doing elevated the educational level of the general population in Nordic countries. That is why it is also referred to as "popular education', which takes place in independent adult education colleges, providing education mainly at upper secondary level beside municipal adult education. Today, in Sweden, there are 154 folk high schools (FIN, 2016). Although the schools are financed by public grants, they are considered to be acting independently and freely educationally and in their curricular planning, be- 
cause there is no national curriculum as a jurisdictional framework for their practice.

Even though their educational approach can be seen as inclusive and open to everyone, their target groups have changed over time, as they are changing still today, even incorporating the educational needs of a wide range of participants such as school leavers without qualifications, unemployed people, immigrants, and so on. By doing so, they have become rather specialized in including heterogeneous groups in their course programme. This development could also be understood as part of a so-called inclusive approach towards their participant groups, and seen as an example of education for all (Ainscow, Booth \& Dyson 2006). As folk high schools are being confronted with certain changes, such as a rising number of participants with disabilities, new ways of thinking about pedagogics have become evident (Nylander, Bernhard, Rahm \& Andersson, 2015). Pupils who received diagnoses as young pupils in school in the 1990s have grown older, and have even become a predominant group within adult education and folk high schools that now have to address their special needs, such as delays and deviations in social behaviour that may even affect the learning situation, and therefore an adjustment of the physical and social learning environment becomes required.

This article sheds light on disabilities within the Swedish adult education system, taking folk high schools as an example. The aim is to give insight into the conditions for and consequences of growing numbers of participants with different types of disabilities. Furthermore, the effects on the Swedish folk high schools' learning environment regarding the changes of participant groups and its challenges are discussed. The following research questions guide the analysis:

1 How has the participant group developed in Swedish folk high schools sin- ce 1997 as regards different types of disabilities?

2 How accessible are folk high schools for learners with different disabilities?

3 What is the staff perception of key factors for a learning environment for successful adult education at folk high schools?

4 In what ways should the learning environment be improved and further developed, according to the staff?

\section{Background: The Swedish folk high school - Some contradictions regarding its organizational form}

Even if the folk high school can be considered as a component of the Swedish educational system, it is still not part of the comprehensive, compulsory, formal school system. Yet folk high schools should mainly be seen as part of upper secondary education, which is formally voluntary but in practice has become more or less obligatory (Fejes et al., 2016). Today, the 154 Swedish folk high schools provide opportunities for supplementing non-finished grades from comprehensive school in their general courses.

Besides the general course, there are the specific courses, and both are classified as long courses (normally one year, or one semester). Whereas the general course serves especially as an alternative to municipal adult education, providing the same eligibility as compulsory comprehensive school or upper secondary school, the specific courses include a wide spectrum of subjects, for example aesthetical and vocational courses. In total, there are three types of course; the third type of course is the short course with varied contents, typically taking place during weekends or summertime.

Folk high schools' guiding objectives target the societal as well as the individual level, 
and include for example the ambition of strengthening and developing democracy, bridging and levelling educational gaps, and providing opportunities for empowerment and influencing ones' life situation. Their roots are to be found within folkbildning. Folk high school's specific motives and ideological focus can vary due to differences in their ownership and organizational models (FIN, 2016; Landström, 2006). Regarding the administrative, even jurisdictional position of folk high schools, they are formally free-standing and autonomous. There is no national curriculum specific to folk high schools, yet their work is determined by some governmental objectives, as the Swedish state contributes through folk high schools to civic education. Furthermore, there are monitoring authorities assessing if and to what extent the schools' public and political tasks are met.

The folk high schools are financed by grants from the state and county councils. With regard to the needs of participants with a disability, there are two main sources of funds to make the teaching better adjusted and more accessible: so-called 'special teaching support' and 'stabilizing strengthening support'. Whereas the special teaching support covers costs for additional staff resources such as support people, and assistants, the stabilizing strengthening support aims to enlarge the teacher capacity, but can also cover costs for psychologists, social workers, and so on. A self-report from the folk high schools regarding their participants' disabilities is required, and serves not only as a basis for applying for financial aid, but also as the basis for statistical information regarding Statistics Sweden. In other words, there is a need for the participant to have a classified disability for the school to be able to apply for financial support through the National Agency for Special Needs. The autonomy of the schools, coupled with the fact that each folk high school decides independently about courses and its educational programme, and even freely designs its teaching, leads to a huge variation regarding educational practice, even with regard to participants with disabilities.

Considering that education at folk high schools aims at developing democratic values and active citizenship, the discourse on inclusion is applied as a conceptual and theoretical linkage between the approach to disabilities and to democratic values (Nilholm, 2006). Inclusion in relation to education, commonly referred to as inclusive education, emphasizes heterogeneous groups, for example learners with disabilities and special educational needs, even groups seen as being vulnerable to exclusion, and draws on the idea of education for all (Ainscow, Booth \& Dyson, 2006). In other words, folk high schools aim for a learning environment accessible to all learners, something which has a legal basis in the 'Convention on the Rights of Persons with Disabilities'. Article 24 on education states, for example, that people with disabilities should have the opportunity to develop their personalities, their talents and creativity, and to participate effectively in a free society. Although the academic discussion on inclusive education refers frequently to school and children, adult learning and disability are being increasingly addressed (e.g. Clark, 2006; Spenceley, 2012). Accordingly, research can be systematized in three ways: (a) meeting diversity in the learning context, (b) sociocultural and economic power issues, and (c) emancipatory self-directed learning approaches.

(a) Disability can be discussed as part of diversity and heterogeneity by taking an intersectional perspective. Hence, disability within an adult (education) learning context is perceived as a matter of diversity, besides dimensions such as gender, race, age, and so on, and also in terms of inclusion. This gains 
importance as educational accommodation requires individualized strategies to be applied. (b) The second topic covers equal access to education, as well as access to higher education, as power issues become evident. (c) The third topic refers to a field where disability creates new experiences of learning, such as identity development and aiming for self-determination due to disability-related restrictions. Taking the case of Swedish folk high schools, and applying the category of 'disability', all three abovementioned fields (Clark, 2006) are seen as relevant, and should be applied.

In addition to that, and taking a deeper look into learning adjustments, the concept of universal design for learning becomes relevant (Scott, McGuire \& Shaw, 2003). It is even stated in article 2 in the abovementioned convention, and can be directly related to questions referring to the learning environment.

Disability within folk high schools is an issue in this part of adult education which aims to provide opportunities for students with difficulties to reach their learning goals (Fejes et al., 2016; Nylander et al., 2015). Attending a folk high school after formal upper secondary education, with the intention to study certain courses and subjects in order to become eligible for higher education, can be recommended, chosen, and fulfilled by people with a disability, as the results of a pilot study show (Bernhard \& Larsson Abbad, in press). This practice has led to the shift in the target group of folk high schools, and this is addressed in this article. Partly, we have chosen a focus on general courses, where changes in the participant group have become most visible. Folk high schools which by tradition are considered to be open to all learners, based on their needs, their previous knowledge and experience - have changed considerably in the last two decades, and have especially widened their tar- get group (Larsson, 2013; Nylander et al., 2015). This could be seen as a result of various adult educational reforms aiming to provide opportunities for finishing and supplementing school degrees as well as increasing the learners' motivation. In other words, the empowerment objective seems to have shifted towards a stronger focus on those not succeeding in comprehensive education, and therefore it focuses to a greater extent on social inclusion.

\section{Methods}

Data for this article are drawn from two sources: Public statistics from Statistics Sweden, and a self-designed online questionnaire targeting headmasters and teachers from 150 folk high schools. ${ }^{1}$

\section{Public statistics}

Data from the public, official statistics, from Statistics Sweden, ${ }^{2}$ were used to get an overview of the participant groups of the general courses at folk high schools over time. The time period for the overview was 19972015. Data for the spring semester during the period 1997-2013 was retrieved for use in Nylander et al. (2015), while supplementary data for 2014-2015 was added for the present article. Data from Statistic Sweden are, with regard to folk high schools' recruitment of participants with a disability, based on self-reports, as described above.

The eight different categories for disabilities applied in Figure 1 follow an administrative classification with medical and psychological distinctions used by Statistics Sweden. However, as the group of hearing and visually impaired was quite small, we decided to put them into one broader category, called 'sensorily impaired'. Therefore, the applied categories in the first part of the results are: neuro-psychiatric disability (e.g. ADHD), mental disability (e.g. depression), dyslexia 
(reading/writing difficulties), medical disability (e.g. epilepsy, diabetes), sensory impairment, intellectual disability, physical disabilities, and brain injury (acquired as adult).

\section{Questionnaire}

The online questionnaire was developed based on consultation with experts from the National Agency for Special Needs, and a literature study. It included mainly quantitative but also a few open-ended qualitative items (see Nylander et al., 2015, for a full description of all items). The questionnaire aimed to provide an overview of the accessibility and adjustment of the learning environment in folk high schools based on special needs. The data also contained background information about the respondents and their schools. In the questionnaire, sensory impairment was specified in the three different categories from the administrative classification - visual impairment, hearing impairment, and deaf / deaf-blind - and the category dyscalculia (difficulties with arithmetic) was added as a category separate from dyslexia.

In the present study, we are employing data from items on: whether the different categories of disabilities are represented at the school; which category represents the highest number of participants; the accessibility of the learning environment for students with different types of disabilities; to what extent a number of factors are perceived as relevant for folk high school courses to be successful for participants with a disability; and perceptions of factors for improvement of the learning environment. In addition to this, open-ended items that provide further information on respondents' views on learning adjustments and improvements are employed.

The online questionnaire allows room for the actors' viewpoint, that is, the perspective of teachers and headmasters, and is to be understood as a complement to more objective data such as those collected and provided by Statistics Sweden.

\section{Respondents}

The questionnaire was distributed to all folk high schools in Sweden (at that moment, 150), and they were asked to submit two responses each - one from the headmaster, or someone with similar responsibilities (e.g. assistant headmaster, or head of a course), and one from a teacher or other staff member possibly involved in courses where participants with disabilities were part of the group. Responses from 121 folk high schools mean a response rate of $81 \%$ among schools. In total, there were 212 responses, which means a response rate of $70 \%$, in relation to 300 possible responses. Among the total of 212 respondents, $43.9 \%$ were headmasters, $17.5 \%$ assistant headmasters or heads of a specific course, $29.2 \%$ teachers in various subjects, $6.1 \%$ special education teachers, and $3.3 \%$ other staff.

\section{Analysis}

The quantitative results are mainly descriptive, based on the public statistics and questionnaire responses. In the section on facilitating factors for successful education, we have also made an analysis to identify possible differences between headmasters (including assistant headmasters and heads of courses) and teachers (including special education teachers and other staff who responded instead of a teacher). In this analysis, a chi square test was applied to identify significant differences. The same type of comparison was made for the answers concerning accessibility for participants with different types of disabilities. However, here no significant differences were found, partly because the numbers in the different groups were too small for the test, when the comparison only included those who were expected to have actual experience of accessibility in relation 
to specific disabilities and special needs. In other words, only those who had reported that the disability in question was represented at the school were included.

The answers from the open-ended questions that were employed in this article have been analysed according to content analysis. The answers were read several times by the researchers and grouped thematically according to content, patterns, and repeating patterns (Mayring, 2014).

\section{Results of the study}

The results section presents the findings in relation to the four research questions. Each part relates to one of the following four issues: development of the participant group regarding disabilities at folk high schools, accessibility for learners with disabilities, key or facilitating factors regarding the learning environment, and improvement of this learning environment.

\section{Changes of or within the participant group towards more disabilities}

A change regarding the participant group in terms of disability and different disability categories was found in an analysis of data from Statistics Sweden for the time period 19972015. The result shows that general courses at the Swedish folk high schools were faced with an increase in the number, and particularly the proportion, of participants with disabilities, that is, in all disability categories. The total number during the spring semester was 2,851 in 1997 , and increased to 4,006 by 2015. At the same time, the total number of students on the general course decreased, from almost 16,000 to slightly more than 11,000. This meant a dramatic increase in the proportion of participants with disabilities. The rise was from $18 \%$ of the participants in 1997 to $36 \%$ in 2015.
We get a far more differentiated picture from the number of participants on the general courses according to the eight different disability categories described above. Figure 1 shows that a neuro-psychiatric impairment or disability is the category that scores highest, including participants with diagnoses such as ADHD and Asperger's. We can see the development in this category since the year 2002, when it was applied for the first time in this national statistic. In figures, the number of participants with a neuro-psychiatric impairment in the general courses increased to almost 1,300. The graph is continuously rising; it is actually the only category that shows a continuous and rapid growth, to have become the biggest category since the year 2013. The number of participants with a mental disability is now similar to the number with a neuro-psychiatric disability, comprising more than 1,200 people in 2015. The third biggest group is participants with dyslexia, reaching more than 700 participants in the statistics for the general courses (Figure 1).

In summary, the analysis of data from Statistics Sweden gives evidence for a growing 'special needs function' at Swedish folk high schools, as the number of participants with disabilities in the general courses has increased, and the proportion has risen to more than every third participant, a growth which is especially strong for the group with a neuro-psychiatric disability.

As we consider data from the online questionnaire, that is, the self-report from the representatives of folk high schools, we get an overview about the perceived presence of different types of disabilities. In other words, we see to what extent folk high schools provide education for participants with different disabilities. In this part, the results are based on one answer from each school, primarily the answers from the headmasters, and cover all types of courses. 


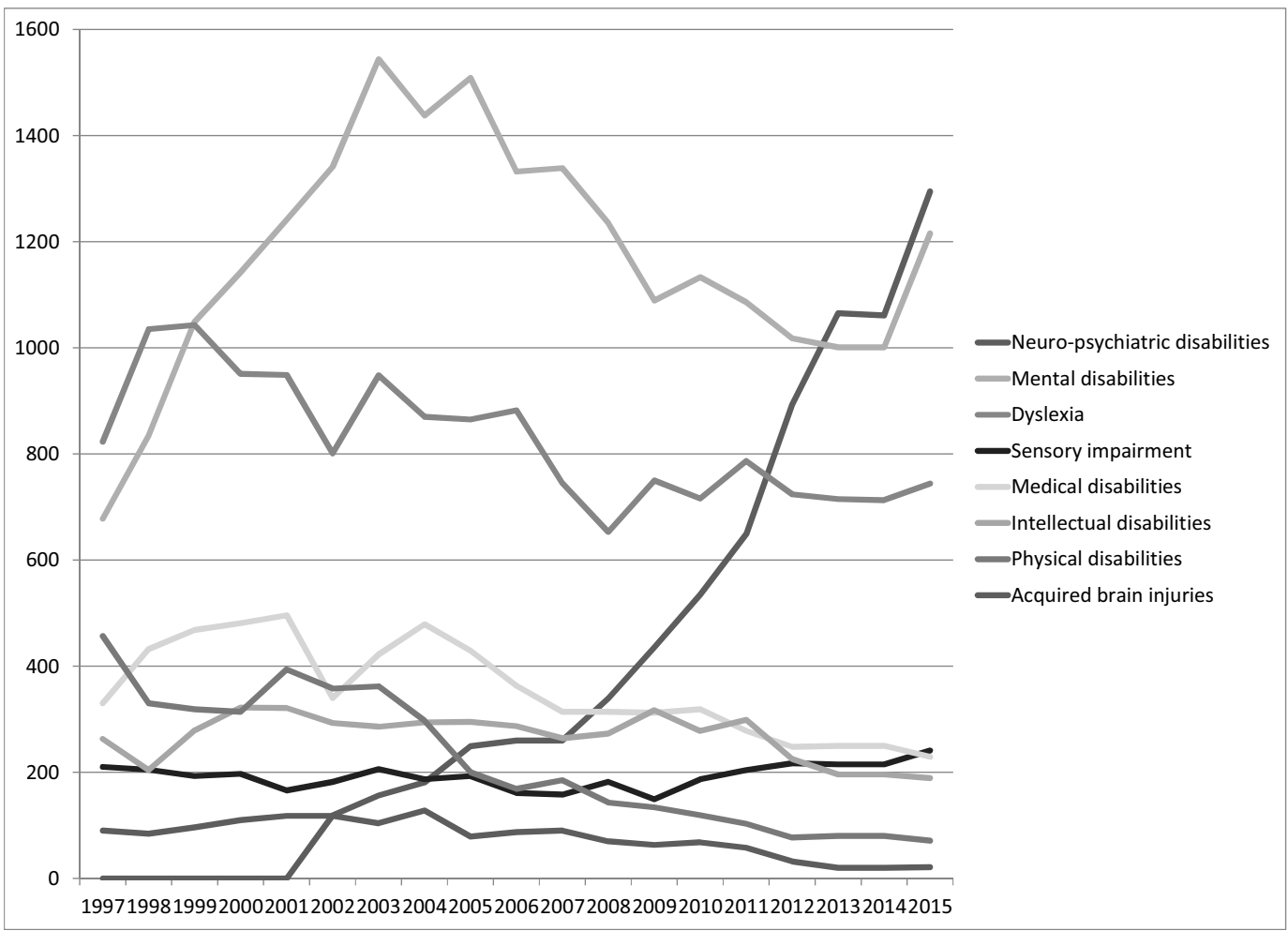

Figure 1: Number of participants in general courses according to the eight different disability categories, spring semester 1997-2015. Source: Statistics Sweden.

Here, 98-99\% of the folk high schools said 'yes' to the question of whether they had participants in the group 'dyslexia, reading and writing difficulties'. Furthermore, we can see that the group with a neuro-psychiatric disability is seen as the second largest group, with over $90 \%$ of folk high schools answering that they had participants with this kind of disability. The third position according to the respondents to the questionnaire, with just below $90 \%$ of 'existence' in the responding folk high schools, refers to participants with a mental disability. The smallest proportion of 'yes' answers refers to the category 'deaf / deaf-blind' with a little more than $10 \%$. It becomes evident that sensorily (hearing and seeing) impaired as a category comes last on the list as it is less common and represents a very small number of participants. Furthermore, concerning which group is perceived as the biggest, $45.5 \%$ chose neuro-psychiatric disability, $17.4 \%$ dyslexia and $14.9 \%$ mental disability.

Regarding the participant group of Swedish folk high schools, both Statistics Sweden and self-reports from the questionnaire give evidence that people with neuro-psychiatric disability are to be seen as a growing group and are even said to be the largest group at Swedish folk high schools regarding participants with a disability. Taking these growing participant numbers and proportion into consideration, we want to analyse possible adjustments and accessibility for these participants with varying disabilities. 


\section{Accessibility of the folk high school for learners with disabilities}

Data from the questionnaire sent to folk high schools allow us to obtain a detailed picture of how staff at the folk high schools assess the accessibility according to the needs of learners with different disabilities (see Figure 2), that is, how well they have adjusted the learning environment to the needs of these participant groups. The diagram refers to those folk high school representatives that have reported to have participants from each disability group at their school, and this number varies between $n=23$ and $n=207$. The reports cover the whole spectrum of courses - general, specific, and short courses.

Accordingly, more than 50\% answer that the learning environment is very accessible and thus relatively well-adjusted to the needs of their learners (i.e. applying to all the eleven mentioned disability categories). Regarding participants with dyslexia, all respondents answer that the learning environment is relatively accessible. The perception of a relatively well-adjusted learning environment relates even to the most frequently named disabilities, which are 'dyslexia', 'neuro-psychiatric disability' and 'mental disability', where more than $75 \%$ of the respondents assessed the learning environment as relatively accessible with regard to these groups.

The diagram even allows for a comment regarding the potential for positive changes of the learning environment. We can see that with regard to those disabilities that entail the biggest groups, about 30\% judge the learning environment as very accessible. Although the learning environment seems to be very well-adjusted for these groups, it could still be improved.

The grade of accessibility in relation to the disability gets the lowest grading regarding participants who are 'deaf / deaf-blind', where about 30\% (one third) say that in this case the learning environment is not at all accessible in relation to the participants' needs. This double category could be an indication of neglect of the special requirements of deaf-blind participants. The fact that sensory impairments (hearing / auditory impairment, and visual impairment / disability) show the lowest accessibility could be an indicator that the representatives are not happy with the adjustments of the learning environment made for this group.

The empirical results also show that less frequently existing disabilities require adjustment to a far more reduced degree, in other words, folk high schools adjust the learning environment in a pragmatic way by functional adjustments according to the real needs in practice among their current participants. Or, if you are considering accessibility in relation to providing for a certain disability at the schools, the data give evidence that those folk high schools reporting to have a certain disability are also those that are more accessible and that have a learning environment that is well-adjusted to their participants' needs. This practice could be considered as a relatively well-functioning adjusted practice.

Qualitative data from the questionnaire provide further information on accessibility and learning adjustments in the cIassroom and indoor environment. The adjustments, that aim to address concentration problems, entail measures such as the cut-back of optical and external acoustic stimuli, for example by using headphones, shades, flexible boards, and walls. Furthermore, the need for measures with regard to planning and structuring lessons, as well as their further development, is emphasized. Accordingly, a daily scheme ought to be visible and easy to understand and to follow, for example by using a whiteboard for visualization. In addition to that, the need for orally repeated tasks is highlighted. Even goals for the lesson ought to be written and 
visualized in an accessible way. 'Time' is especially assessed as relevant in relation to study planning as a measure, since there is even giv- en an opportunity for reduced studies, fewer courses, extra mentoring time, as well as the application of individual study plans.

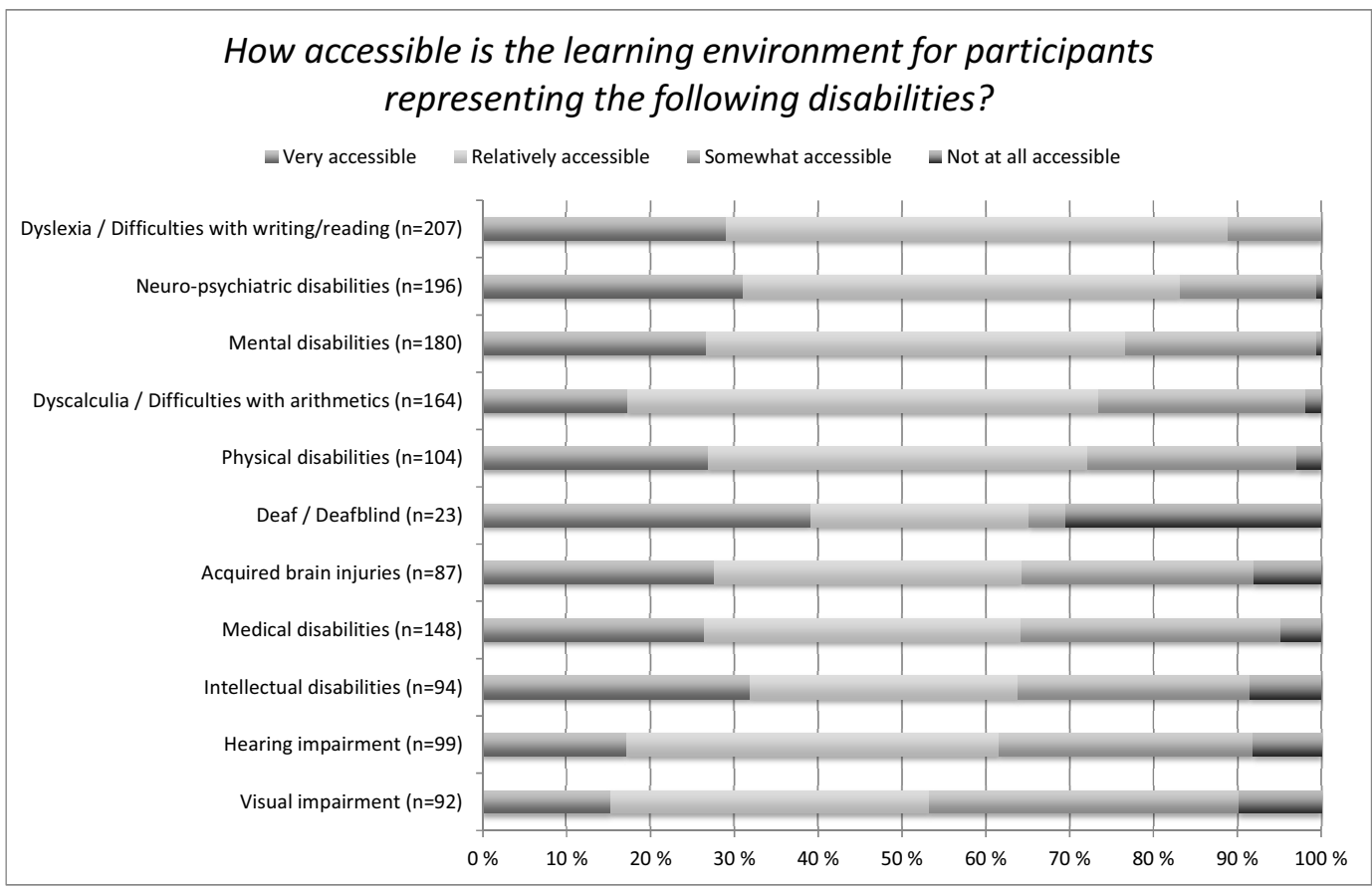

Figure 2: Accessibility of the learning environment for participants with different disabilities, based on answers from folk high schools where they have participants with the abovementioned disabilities ( $n$ varies between 23 and 207).

To sum up, the data allow for the conclusion that the accessibility measures in place at Swedish folk high schools refer to the needs of the participants. In other words, accessibility is steered by real and actual participants' needs. Yet these needs are not always fully met.

\section{Staff perceptions of key or facilitating factors in the learning environment for a successful education with regard to disability}

The third research question asked what factors are of importance for successful education for participants with disabilities. In this section, we will present findings regarding the staffs' perceptions in relation to this question, and here too the responses relate to the whole spectrum of courses. The analysis of data from the questionnaire shows that all factors included in the items are somewhat meaningful to the respondents (Figure 3). The factor that seems to have least meaning is 'residential environment', which was rated as 'not at all' relevant, to the highest extent. Yet there are still more than $50 \%$ that assess the boarding possibility to a very high or rather high extent as a success factor, although one has to consider that not all the schools have boarding facilities, and even if they have, not all participants live in them. Thus, boarding is relevant to certain students 
at many schools, but is not relevant to all participants with a disability at all folk high schools. The factor 'voluntary participation' is also seen as not at all relevant by rather many, yet it becomes irrelevant if a participant actually wants to participate. With regard to the welfare state actors, such as the national insurance authority, or the employment office, who also have the task of providing for courses, voluntary participation becomes challenged, for example if the individuals are required to participate to remain eligible for their unemployment benefits (Nylander et al., 2015).

The factors perceived as leading to successful education for participants with a disability include two highly relevant aspects:

1 Pedagogics based on participants' needs

2 Personalized relations between staff and participants

96 As seen in Figure 3, more than 95\% of the respondents see these factors as relevant, to a very or rather high extent, for the folk high school to be able to provide successful courses. 'Pedagogics based on the participants' needs' is seen as most important and most relevant for folk high schools to be successful for participants with a disability. Accordingly, an ability to see the participants' personal development, as well as the potential to challenge the person, are emphasized. This pedagogical approach goes with providing personalized and individualized support, which can even make investigation of relevant support people at folk high schools necessary. To sum up, it is the pedagogics and relations that are identified by the respondents as very important.

About $90 \%$ of the participants say that 'knowledge about disabilities' is a very important factor as regards being able to successfully work with participants with a disability. Having such knowledge seems to be important for the teachers to approach these participants in a self-confident and professional - that is, successful - way. This is supplemented by the factor 'a special educational approach', which is seen as leading to success to a very or rather high extent by $80 \%$ of the respondents. Although the meaning or value of 'knowledge about research and development' is not seen as high, it is still seen as a factor that can lead to a certain success.

The factors that show similar patterns in the answers, 'comprehensible goals and follow ups', 'size of group of participants', 'participants involved in designing their studies', and 'physical accessibility', are all factors relating to the design and planning of education. They are seen as relevant, but not to an extreme extent. One example of practice was to exchange knowledge and impressions about students' health and individual study situation between colleagues in an informal way in daily work routines such as teacher meetings. The content of these talks may vary, but often they entail an exchange of information about participants.

About $60 \%$ of the respondents answer that the use of technical aids for learning is relevant for participants with a disability, and as such it is almost the least relevant factor (among those covered in the questionnaire) for folk high schools to be successful in relation to this group. Technical aids or features are used to support learning, and are said to be especially relevant for those students who are in need of special support. Folk high schools' staff provide help primarily with compensatory measures, tools and adjustments. A number of technical support measures are in place, yet often they are not widely used.

Here we have also compared the answers from headmasters (including assistant headmasters and heads of courses) and teachers (including other staff who responded). There were few significant differences in the distribution. The only significant difference $(\mathrm{p}<.05)$ concerned physical accessibility, 
where teachers saw this factor as more important than the headmasters. Furthermore, there were weak indications of significance $(p<.1)$ for the factors 'size of the group', and 'voluntary participation'. Here too, these factors were seen as more important among teachers than among headmasters.

To sum up, the factors allowing success at folk high schools are 'pedagogics based on participants' needs' as well as 'personalized relations between staff and participants'. Factors regarding design and planning of education and courses are seen as less relevant, and less important in terms of providing successful courses for participants with a disability. The differences between headmasters and teachers are small, but when there is a significant difference, this means that teachers see the factor in question as more important to be successful.

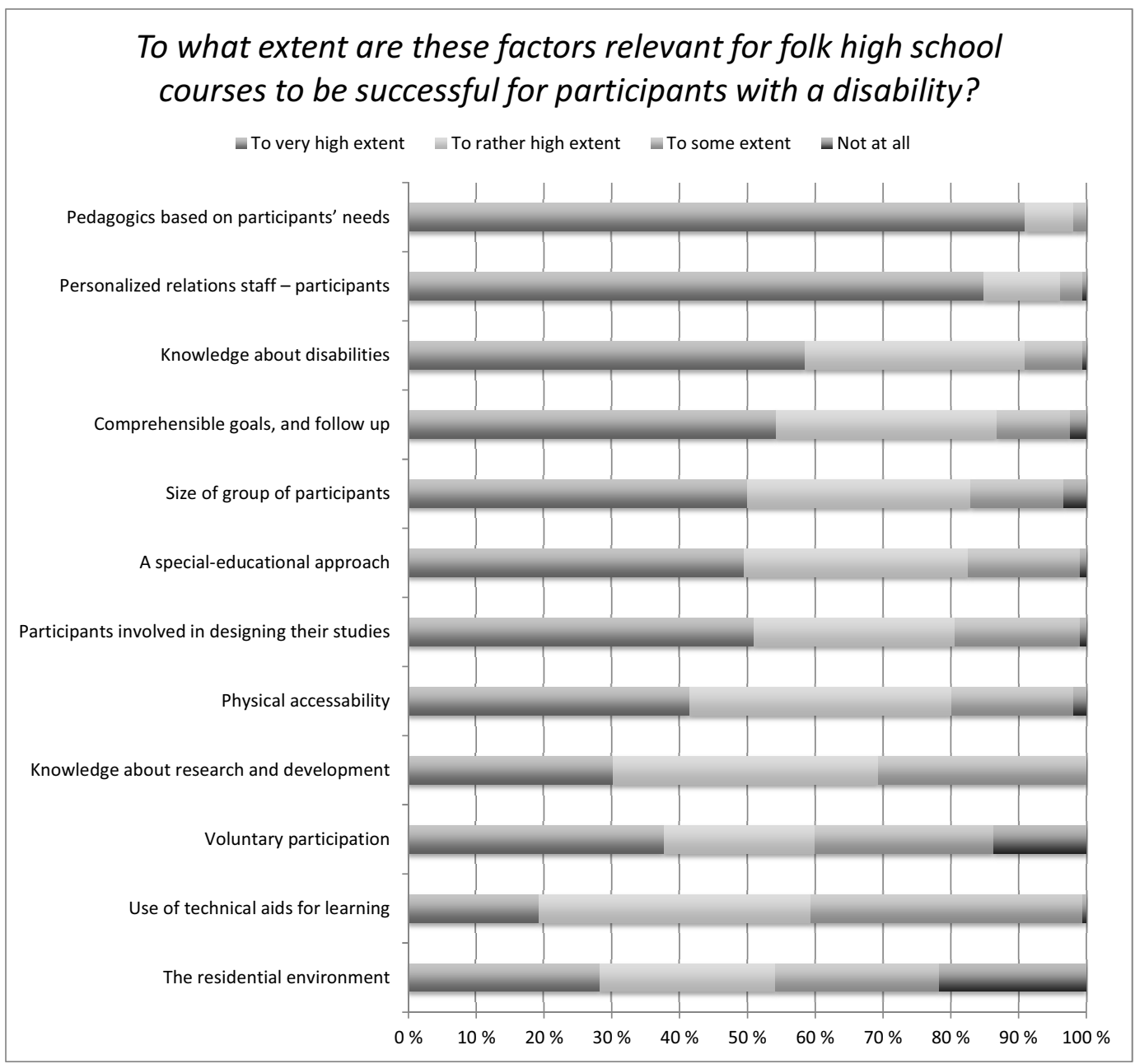

Figure 3: Success factors for studies at folk high schools for participants with disabilities $(n=2 / 2)$. 


\section{Staff perception of factors for} improvement of the learning environment

The fourth research question concerned what the respondents consider important to change and further develop in the folk high schools to achieve a better learning environment for participants with varying disabilities. This question is linked to the aforementioned and presented facilitating factors, yet it is something different. One could think that factors that are seen as important to change, should be seen as important to be successful too, but there may also be factors that are perceived as important but where a need for change does not exist, or which are not addressed as the local practice already works well.

The more extensive quantitative results presented in Nylander et al. (2015) show that knowledge and competence growth among staff are factors seen as important for further adjusting the learning environment in Swedish folk high schools. The most important factors are seen to be: developing knowledge about the various disabilities; and a special educational approach. These could impact upon the learning environment to a notable extent. Also knowledge about research and development scores relatively highly regarding the need for change and development. In other words, and in summary, folk high schools express a strong need to develop competences in relation to disability and special education.

Regarding the abovementioned factors (e.g. competence development), it is exemplified in the qualitative answers of the questionnaire that more formalized forms of professional development for staff, such as courses, are seen as a way to gain new insight regarding 'disability'. This is especially seen as relevant in relation to certain neuro-psychiatric diagnoses such as ADHD, ADD, and Autism spectrum disorder, but also in relation to dyslexia. In addition to disability-related knowledge, a desire to learn more about teaching methods, as well as different learning types and traditions, is also expressed in the answers. Although the respondents answer that they feel prepared for their teaching practice, they request competence development in relation to the widening of participant groups, that is, gaining knowledge in the field of 'special education' with regard to different disabilities.

Another field given a high priority to be further developed is the use of technical aids for learning, even if this was judged less important as a success factor. Even the qualitative data supports this, as the handling of technical aids is seen as a field for development; technical competence and self-confidence in using devices are perceived as lacking. The respondents state that aids exist, but they are not being used, and therefore a need for further education and time for exploration is mentioned (see Nylander et al., 2015).

Furthermore, relating to the quantitative results (ibid.), items such as 'Pedagogics based on participants' needs' and 'Personalized relations between staff and participants' are not given the highest priority in terms of developmental needs. Although important, these factors are still well-functioning and therefore not related to the need for change.

\section{Discussion: Special needs at folk high schools and inclusion as the solution?}

The discussion takes its starting point in the jurisdictional framework and political intention of folk high schools under the notion 'free and voluntarily' to problematize the increase in number of people with disabilities who might not really be participating freely and voluntarily. Furthermore, we consider success factors such as pedagogics and personalized relations and their meaning with regard to people with disabilities, and end by 
indicating a need for further education for adult educators. The research questions provide a structural frame.

Referring to the first research question, for example the change of population at folk high schools, we raise issues related to an organizational level as folk high schools lack a national curriculum, yet within the educational system provide for complementary secondary education. This results in a dilemma as the complementary courses cover both voluntary and compulsory education. To expand this idea, folk high schools are on the one hand open to all learners, and on the other hand they serve as collaborating partners of welfare authorities such as the national employment office by providing courses and measures for disadvantaged groups in order to improve their chances for labour market inclusion. Building on an educational system and the national discourse on education, it should be highlighted and discussed to what extent and why the Swedish school discussion excludes the discourse about adult learning and further education. Given the fact that an overview of the Swedish educational system by the National Agency for Education (Skolverket, n.d.) includes folk high schools, one wonders about these schools' position in the school system. The study has even brought evidence about growing groups with disabilities in the general courses, which can be seen as a result of failure of the comprehensive school as well as the non-compulsory (yet, in practice compulsory) upper secondary education at gymnasieskolan), by not providing for a learning environment where its pupils can reach their goals. Even if we cannot explain this phenomenon by means of our empirical data, we can help to better understand recent developments within the educational sector. For example, could the growing number of folk high school participants with - particularly neuro-psychiatric - disabilities from the year 2002 onwards possibly be explained by a group of children diagnosed in the 1990s, that simply became young adults in the early 2000 s and that did not manage to finish comprehensive compulsory school, or the upper secondary school, and therefore ended up at folk high schools? Furthermore, the growing number of people with a disability and their appearance in adult education could also be seen as an international phenomenon (see also Chown \& Beavan, 2012; Clark, 2006; Spencely, 2012), but it could even have to do with a growing acceptance in Swedish society towards disability diagnoses (Svenaeus, 2013, 2015).

Regarding research question 2, the accessibility for learners with a disability shows variations in relation to the different disability categories. This can even be linked to possible provisions regarding an adjustment of the learning environment. We should take into consideration that one of the interests and missions of the National Agency for Special Needs is to support and provide for a learning environment according to the disabled participants' needs, given that the folk high schools have announced the need for support (to report which participants have a disability as this is a criterion to apply for and receive support). This support system could even imply limitations of the present study, as it should be mentioned that the National Agency commissioned the research. As experts, agency representatives provided ideas and proposals on the focus of the study in the phase of designing the online questionnaire by consulting, and as such they participated in the research process.

Research question 3 on facilitating factors regarding the learning environment refers to personalized relations, to personal encounters and pedagogics based on participants' needs (an individualized approach). With regard to the reliability of the results, it can be stated that the majority of the respondents were teachers in general courses and not in 
specific courses, which are often designed for groups of people with disabilities. Therefore, we might have missed some aspects related to the special circumstances in such specific courses. However, as our starting point in this study has been the development of participant groups in the general course, the experiences of the responding teachers should be more relevant based on their teaching context. Furthermore, the collection of data occurred at the beginning of the autumn semester at the folk high schools. There is a risk that the respondents filling in the questionnaire did not have a full overview of their students yet and the group they would be dealing with over the semester or year to come. One could guess that some adjustments happened later on (following a socalled 're-active' instead of a 'pro-active' approach), during the semester, after teachers had gained a better understanding of the individual students' needs.

With reference to question 4 and the potential for further development of the learning environment, it can be stated that the growing numbers of participants with disabilities at folk high schools is mirrored in how teachers experience their working conditions, for example they call for competence development regarding knowledge about disabilities. The wish to develop knowledge about participants with disabilities and special needs is not only a result of our study but became evident in Andersson's et al. (2013) research, and could even be seen as one of the new challenges concerning the participant group. There is competence and knowledge at the folk high schools regarding special education, but it is not always formalized. For example, very few teachers have a special needs teacher or a special educational needs coordinator (SENCO) degree. In other words, the formal competence is restricted. Interestingly enough, a total population study of both degrees (referred to as special educators) by Göransson, Lindqvist and Nilholm (2015) does not take into consideration the possibility of special educators working within adult education. This should just be seen as another example of the neglect of adult learning within special needs and inclusive education. The competence discussion coupled with the call for knowledge on disability is even linked to the most relevant success factors regarding the learning environment that were identified: 'pedagogics based on the participants' needs' and 'personalized relations between staff and participants', aspects that have also been found important in other research. Baric et al. (2016) have found individualized teaching methods and caring teachers as part of practical and emotional support systems to be relevant factors for a successful learning environment for people with neuro-psychiatric disabilities. These factors can be seen as essential for ensuring good conditions for taking care of people with disabilities.

Even if folk high schools, as part of the lifelong learning sector, recently seem to have started a new discourse on special needs (see Spenceley, 2012), traces of this discourse could be found as early as the mid-1980s when folk high schools were described as 'an avenue for the education and integration of young adults with special needs' (Juul, 1985, p. 121). However, the ongoing international discourse on special needs has shifted in the meantime, arguing and aiming for inclusive education, which calls for incorporating adult learning to a greater extent. Clark's (2006) systematization of the field 'adult education and disability' with educational accommodation due to diversity, with questions of access to courses and individual learning opportunities, is mirrored in our results. Our study contributes to a possible discourse on inclusion according to the principle of education for all. Yet it can be questioned to what extent identity development 
and empowerment as part of individual learning opportunities (see Clark, 2006), which also serve as important characteristics of Swedish folk high schools, should be seen to be central when courses are obligatory, and the notion of schools acting independently and freely gets challenged through welfare actors' influence and impact.

There is a question about whether teachers at folk high schools should be specially trained and prepared to be able to handle the specific needs of new and growing participant groups, or whether they should continue working with their open approach, which is considered typical for this specific lifelong learning sector. It might be that competence development in the area discussed here could help the teachers and the folk high schools to solve the dilemma. If the special needs could be met within the open approach that partly results from the lack of a national curriculum, and with more comprehensive and elaborated competence on special education among teachers and other staff members, then folk high schools would be even better prepared for meeting diversity in the participant group.

\section{Endnotes}

I The data collection took place in August 2014, when there were 150 folk high schools in Sweden. Four new schools have been added since then.

2 http://www.statistikdatabasen.scb.se

\section{References}

Ainscow, M., Booth, T. \& Dyson, A. (2006). Improving schools, developing inclusion. Routledge: London.

Andersson, P., Rudberg, K., Rydenstam, K. \& Svensson, L. (2013). Att vara folkhögskollärare: Förutsättningar, kompetensbehov och tidsanvändning. Stockholm: Folkbildningsrådet.

Bernhard, D. \& Larsson Abbad, G. (in press). Included or excluded? Looking in the mirror and reflecting on special education in school of young adults with autism spectrum disorder.

Bolic Baric, V., Hellberg, K., Kjellberg, A. \& Hemmingsson, H. (2016). Support for learning goes beyond academic support: Voices of students with Asperger's disorder and attention deficit hyperactivity disorder. Autism, 20(2), 183-195. DOI: $10.1177 / 1362361315574582$

Chown, N. \& Beavan, N. (2012). Intellectually capable but socially excluded? A review of the literature and research on students with autism in further education. Journal of Further and Higher Education, 36(4), 477-493. DOI: 10.1080/030987 7X.2011.643771

Clark, M.A. (2006). Adult education and disability studies, an interdisciplinary relationship: research implications for adult education. Adult Education Quarterly, 56(4), 308-322. DOI: 10.1177/0741713 606289661

European Commission (2011). Council Resolution on a renewed European agenda for adult learning. 2011/C 372/01, Official Journal of the European Union, pp. 16 Online: http://eur-lex.europa.eu/legalcontent/EN/TXT/?uri=uriserv:OJ.C_. 2011.372.01.0001.01.ENG [12.09.2016]. Fejes, A., Olson, M., Rahm, L., Dahlstedt, M. \& Sandberg, F. (2016). Individualisation in Swedish adult education and the shaping of neo-liberal subjectivities. Scandinavian Journal of Educational Research, published online. DOI: 10.1080/ 00313831.2016 .1258666

FIN. (2016). The Swedish folk high school. Stockholm: Folkhögskolornas informationstjänst. Online: https://www.folkhogskola. 
nu/globalassets/documents/folkhogskola_eng_engelska.pdf [14.02.17].

Göransson, K., Lindqvist, G. \& Nilholm, C. (2015). Voices of special educators in Sweden: a total-population study. Educational Research, 57(3), 287-304. DOI: 10.1080/00131881.2015.1056642

Juul, K.D. (1985). The Scandinavian folk high school: A model for the education and integration of handicapped youth. The Exceptional Child, 32(2), 121-127. DOI: $10.1080 / 0156655850320209$

Landström, I. (2006). Folkhögskolan förr och nu möter framtiden. In L. Borgström \& P. Gougoulakis (Eds.) Vuxenantologin: En grundbok om vuxnas lärande (pp. 153185), Stockholm: Atlas.

Larsson, S. (2013). Folk high schools as educational avant-gardes in Sweden. In A.M. Laginder, H. Nordvall \& J. Crowther (Eds.), Popular education, power and democracy. Swedish experiences and contributions (pp. 72-96). Leicester: NIACE.

Mayring, P. (2014). Qualitative content analysis: theoretical foundation, basic procedures and software solution. Klagenfurt. URN: http://nbn-resolving.de/ urn:nbn:de:0168-ssoar-395173

Nilholm, C. (2006). Special education, inclusion and democracy. European Journal of Special Needs Education, 21(4), 431-445. DOI: $10.1080 / 08856250600957905$
Nylander, E., Bernhard, D., Rahm, L. \& Andersson, P. (2015). oLika TillSAMmanS. En kartläggning av folkhögskolors lärmiljöer för deltagare med funktionsnedsättningar. Linköping: Linköping University Electronic Press, Studier av vuxenutbildning och folkbildning, Nr. 7.

Scott, S., McGuire, J. \& Shaw, S. (2003). Universal Design for instruction. A new paradigm for Adult instruction in Postsecondary Education. Remedial and Special Education, 24(6), 369-379.

Spenceley, L. (2012). 'The odd couple': An FE educator's perspective of the management of behavior of 'special need' learners in the lifelong learning sector. Research in Post-Compulsory Education, 17(3), 311-320. DOI: 10.1080/13596748.2012. 700099

Skolverket (n.d.). The Swedish Education System. Online: http://www.skolverket.se/polopoly_fs/1.179241!/Menu/article/attachment/SVUS-Original-2012EN.pdf [14.09.2016].

Svenaeus, F. (2013). Homo Patologicus. Hägersten: Tankekraft förlag.

Svenaeus, F. (2015). ADHD som en samtida kulturdiagnos. Socialmedicinsk Tidskrift, 92(1), 56-62. 